\title{
Corporate Social Responsibility Among Saudi Arabian Firms: An Empirical Investigation
}

Saud Mandurah, King Abdulaziz University, Saudi Arabia Jamal Khatib, University of St. Thomas, USA

Saleh Al-Sabaan, King Abdulaziz University, Saudi Arabia

\begin{abstract}
There is an increasing recognition within the developed economies across the world that today, CSR is not an optional extra; i.e., firms can no longer look at CSR as a luxury or an indicator of their goodwill toward society. Firms, in today's context, are seeking to integrate CSR in their corporate policies and strategies. Developing countries' firms, however, are still in the early stage of their awareness and integration of CSR activities within their corporate policies and strategies. The present exploratory study utilizes a sample of Saudi Arabian firms' managers to assess the extent of their awareness of CSR, its role within their organizations, the extent of CSR integration in their corporate policies, and the nature and scope of these firms' CSR activities. Results indicate that there is a reasonable level of CSR awareness as well as a moderately positive attitude toward the concept. However, most CSR activities in Saudi Arabia seem to focus on the local communities in which these firms operate. Discussion of the results and their implications are provided.
\end{abstract}

Keywords: Corporate Social Responsibilities (CSR); CSR Activities; Developing Countries; Saudi Arabia

\section{INTRODUCTION}

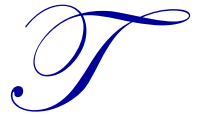

here is a growing interest in the notion of Corporate Social Responsibility (CSR) within many market participants such as companies, investors and regulators (Mackenzie, 2007). In today's world of heightened awareness regarding the concept of CSR, many firms in the western world view noncompliance with CSR standards as a significant source of risk to their reputations with customers, employees and other stakeholders. Recent evidences from the business world, such as the effect of the sweatshop scandal on Nike's reputation or the dishonest and fraudulent practices at Enron and its resultant demise, lend credence to these concerns.

Although CSR has begun to receive greater attention recently, this topic is not new to academics and practitioners alike. Academicians have been debating this area for over 75 years and yet there is no universally accepted definition of the term (Votaw, 1973; Whitehouse, 2003). Broadly, scholars have defined CSR as a "situation where the firm goes beyond compliance and engages in 'actions that appear to further some social good, beyond the interests of the firm and that which is required by law" (McWilliams et al., 2006). As scholars suggest, CSR is not simply about avoiding risk. Relatedly, firms have begun to view this as an area of opportunity in that a strong performance/rating in this area may strengthen customers' trust in firms' brands and also enhance employee motivation. In addition to business benefits, there is a view that many of the most basic CSR obligations are also legal requirements.

Extant evidence suggests that an increasing number of firms are establishing programs aimed at improving their firms' CSR and also periodically publishing CSR reports. As of early 2006, 73 of the UK's largest 100 listed 
companies have issued a public statement indicating the CSR principles that they accept (Ethical Investment Research Service, 2006).

The above discussion, as well as a critical review of the CSR literature (e.g., McWilliams et al., 2006; Collier and Esteban, 2007; Mackenzie, 2007) suggests that firms in the United States, the EU, and developed economies in Asia (e.g., Japan, Korea) are at the forefront of thinking about and implementing CSR programs. It is also heartening to see that within the developing economies in Asia and Africa (Levine, 2008; Goyal, 2007; Ford, 2007), there is an increasing awareness of CSR. The experience in the Middle East is not different either. We have begun to see evidences of firms in some GCC countries (e.g., UAE, Qatar) actively thinking about CSR, what it means, and how to incorporate it in principle and practice.

Saudi Arabia, a member of the GCC, is a host to many important industries such as petrochemicals and refining, banking, and healthcare. In recent years, Saudi firms have started paying attention to CSR and have begun to show greater commitment in terms of instituting CSR guidelines and programs. However, their efforts are likely to be slowed since there are no guiding theoretical and practical frameworks that have examined this phenomenon, exclusively within Saudi context, which they could depend upon. It is therefore plausible that these efforts will be aided greatly if Saudi firms had access to primary research, which would highlight to them how key Saudi business managers who, in the future, will play a crucial role in crafting the CSR policies for Saudi firms thinking about CSR.

Our project objectives, which we outline next, speak to these gaps in our extant understanding of CSR in Saudi context. Owing to the importance of thinking about CSR for Saudi firms and the lack of extant knowledge in this area within Saudi context, the major objective of this project is to take a holistic perspective of this area and assess the extent to which CSR, as a part of the corporate philosophy, has made inroads among Saudi firms. The specific research questions we will study in this regard are:

1. What is the level of awareness and attitude among Saudi Arabian managers towards CSR?

2. What is the extent of integration of CSR policies into the overall corporate policy?

3. What type of CSR activities are currently implemented in Saudi Arabian organizations? Specifically, what types of activities are taking place to enhance:
A. The environment
B. Local community
C. Customers
D. Employees

Below we review the literature on CSR in the context of experiences of developed and developing economies. We also focus on the experience within the GCC countries. We then briefly describe the study's methodology. The results and discussion will be presented and implications of the results and directions for future research will conclude the paper.

\section{LITERATURE REVIEW}

\section{CSR in the Developed and Developing World}

The term CSR is generally used to refer to the obligation of the firm, beyond self-interest and what is required by the law, to use its resources in ways to benefit society (Snider et al., 2003; Jamali and Neville, 2011). The European Commission defines CSR as a "concept whereby companies integrate social and environmental concerns in their business operations and in their interactions with stakeholders on a volunteer basis." (2002, p. 25).

Today there is an increasing recognition within the developed economies around the world where CSR is not an optional extra - i.e., firms can no longer look at CSR as a luxury or an indicator of their goodwill toward society. Firms, in today's context, are responsible not only for their conduct, but also for the overall impact their businesses may have on all their stakeholders now and in generations to come (Collier and Esteban, 2007). Within the US and European firms, it is becoming increasingly known that it is not enough to have mission statements and 
codes of ethics regarding how firms may behave; it is necessary for ethics and CSR to become embedded in the cultural fabric of the business, as well as in the hearts and minds of its members.

In predominantly western contexts, CSR has been investigated through various angles, such as firm's ethical values and its impact on earnings management, emphasis on sustainability (Ferns et al., 2008), concerns toward green marketing (Dubey, 2008), environmental issues (Ford, 2007), or good corporate citizenship (Ingham, 2006), and from an institutional perspective (Jamali and Nevillle, 2011). From an operational standpoint, scholars have studied aspects, such as incorporating social characteristics or features into products and manufacturing processes (e.g. developing environmentally-friendly technologies), adopting progressive human resource management practices (e.g. promoting employee empowerment, providing acceptable work environments to employees), achieving higher levels of environmental performance (e.g. through recycling, adopting an aggressive stance toward reducing emissions), and advancing the goals of community organizations (e.g. working closely with groups, such as United Way or many other non-profits that are active in social sectors) (McWilliams et al, 2006).

Corporations and governments of developing economies are also increasingly appreciating the importance of CSR. As Levine (2008) highlights, China's stock exchanges and agencies have started issuing regulations on corporate social responsibility (CSR), which are providing businesses in China a new incentive to implement CSR programs. It is indicated that failure to abide by CSR standards may result in fines and punishments. Specifically, major Chinese stock exchanges are issuing guidelines encouraging companies to assume responsibility for social development, protect the natural environment and other resources, and commit to advancing the interests of multiple entities such as shareholders, creditors, employees, customers, consumers, and others involved with their business. As mentioned earlier, these guidelines are coupled with incentives. For example, for listed companies that promote CSR in China, the Shanghai Stock Exchange offers incentives, such as priority election into the Shanghai Corporate Governance Sector, which may benefit a company's public image, or simplified requirements for examination and verification of temporary announcements.

\section{CSR in Africa and the Middle East}

Several studies focusing on CSR among developing countries' firms concluded that CSR among these firms tends to be anchored in a mix of personal and religious motivations, reflecting in a spontaneous altruistic philanthropic CSR orientation, and CSR activities tend to be less formalized, more sunken and primarily oriented toward the local community in which the firm operates (Jamali et al., 2009; Amaeshi et al., 2006; Visser, 2008).

In African context, Ford (2007) notes that encouraging the growth of African companies and creating employment can be difficult enough without placing any restrictions on the approach of business. Nonetheless, he observes that firms operating in African environments are becoming increasingly sensitive toward combining development with sustainability and treating employees and the society within which companies operate with respect. The environmental impact of any economic activity should be weighed against the economic benefit and any measures that could mitigate the negative impact should be taken if they are at all economically feasible. Amaeshi et al. (2006) explain that CSR among African firms is not culturally embedded but also provides a social buffer where public institutions are weak.

While the awareness regarding CSR is on the rise in the Middle East, in today's context, most CSR activity in this region is performed mainly by western multinational corporations (e.g., Intel, DHL, Shell, etc.) and we see little initiatives taken by local businesses in this direction (Katsioloudes and Brodtkorb, 2007). It is crucial that the local companies take this issue seriously since the World Bank has identified good governance and accountability as a major element necessary for economic growth and sustainability in the Middle East region. Academics in this region are busy documenting the region's best practices of responsible business conduct since it is widely believed that it will be a useful learning tool for business professionals and students in the Gulf region.

Katsioloudes and Brodtkorb (2007) conducted an extensive assessment of the concept of CSR in the United Arab Emirates (UAE). Their findings suggest that there is a strong, yet indirect, awareness of the importance of CSR among the UAE corporate managers. Firms in this region are sensitive toward environment, community affairs, and consumers. Nonetheless, these firms seem to lack a firm grasp of the concept of CSR as promulgated in Europe and 
America. Further, clearly defined CSR policies and practices are rare in this region, except in cases where they simply comply with the country's laws in specific areas. Their research further revealed that UAE firms don't know where to begin formulating CSR policies and practices that would satisfy international standards. To promote a greater dialog regarding CSR, the Dubai Ethics Resource Centre recently launched a series of training seminars specifically tailored to the needs of executives in the UAE and Gulf markets. Among other things, the training sessions have been designed to develop the CSR knowledge required by business professionals to manage a variety of related programs, strategies, and infrastructures.

Khan (2008 - http://www.zawya.com/story.cfm/sidZAWYA20070509115334), while discussing CSR in GCC countries, mentions that firms in this region need formal CSR policies so that corporations may play an important role in aiding the pace of development in the education, health, housing and environment sectors on a sustainable basis. He further notes that governments within the GCC region feel that social sectors, such as education, health, housing and environment, are their sole responsibility; accordingly, corporate sectors exert little efforts in this area. He highlights three ways in which CSRs are enacted by firms within this region. The first approach - Public-private partnerships (PPP) - entails the government and private sector teaming up, as in the case of Tameer Group which, within the UAE and MENA region, has initiated the large-scale project of developing a complete city (Al Salam City) in the Emirate of Umm Al Quwain (UAQ). The second way of implementing CSR is providing incentives to the corporate sector for CSR contributions in the form of preferred treatment or giving annual awards to the "Best CSR" corporate entities. The third manner is corporations managing certain activities, such as establishing schools, colleges, or vocational training facilities.

Qatar National Bank (QNB) - the leading national bank in Qatar - is committed to the notion of CSR. As their Chairman notes, "We believe that successful organizations must always aim to be the best they can be - and more. If they are to be effective leaders, they must take their role one step further and give generously to the community of people who fuel their success." (QNB CSR Report 2007) It is worth noting that QNB publishes the CSR Report every year. As the bank's website (http://www.qnb.com.qa/qnb/DocIndex.jsp?currentPage= QNBCorporateSocialPublications\&LangPref=en) mentions, this report “....aims to help banks' stakeholders understand and appreciate how QNB have, for more than four decades, focused on ensuring that the community and the country meet their full potential." The bank further states that the aim of the report is also to show how it intends, in future, to continue to go "Together Forward" in fulfilling its social responsibility commitments. QNB's CSR statement indicates that they have established standards and guidelines to guide its CSR activities that involve sponsorship opportunities, event participation, financial and in-kind donations, and partnerships with officially sanctioned charities. In addition, the bank is committed to allocating a designated percentage of its annual net profits to provide general support through the above-noted channels within eight broad realms, such as arts and culture, economic and international affairs, health and environment, social and humanitarian activities, sports, youth and education, staff engagement, and staff support.

Overall, the extant academic literature and evidence from the western and the GCC region provide a sound foundation for this study, which aims to gain first-hand insight into the notion of CSR within Saudi context and also come up with a normative model for Saudi managers. We describe our proposed methodology next.

\section{STUDY DESIGN AND METHODOLOGY}

As noted earlier, the awareness within the Kingdom of Saudi Arabia regarding CSR has just started growing. While we can use insights from the experiences of other GCC countries as a starting point in our investigation, our study objectives demand that we understand first-hand from Saudi managers, their perspectives about this issue. Accordingly, we employed the survey method. Our survey respondents with be Saudi business managers who are likely to play a key role in articulating the CSR policies of their firms. A self-administered survey was developed in English and translated into Arabic and was hand-delivered to a sample of 120 managers operating in various sectors of the economy in the city of Jeddah, the commercial capital of Saudi Arabia. Respondents were recruited using the two techniques - word of mouth and use of local chamber of commerce business directories.

Respondents of the study were informed of the objectives and were asked for their consent to be included in the study. Three research assistants were recruited for the data collection task and they were instructed to drop the 
survey off at the identified respondents' place of employment. The research assistants returned and collected the completed surveys after about one week. The instrument is consistent with the proposal objectives and issues we are interested in studying. Of the total 120 surveys distributed, 78 complete and usable surveys were received, yielding a response rate of $65 \%$. Table 1 provides a summary of the sample demographic profile.

Table 1: Demographic Profile of the Sample $(N=78)$

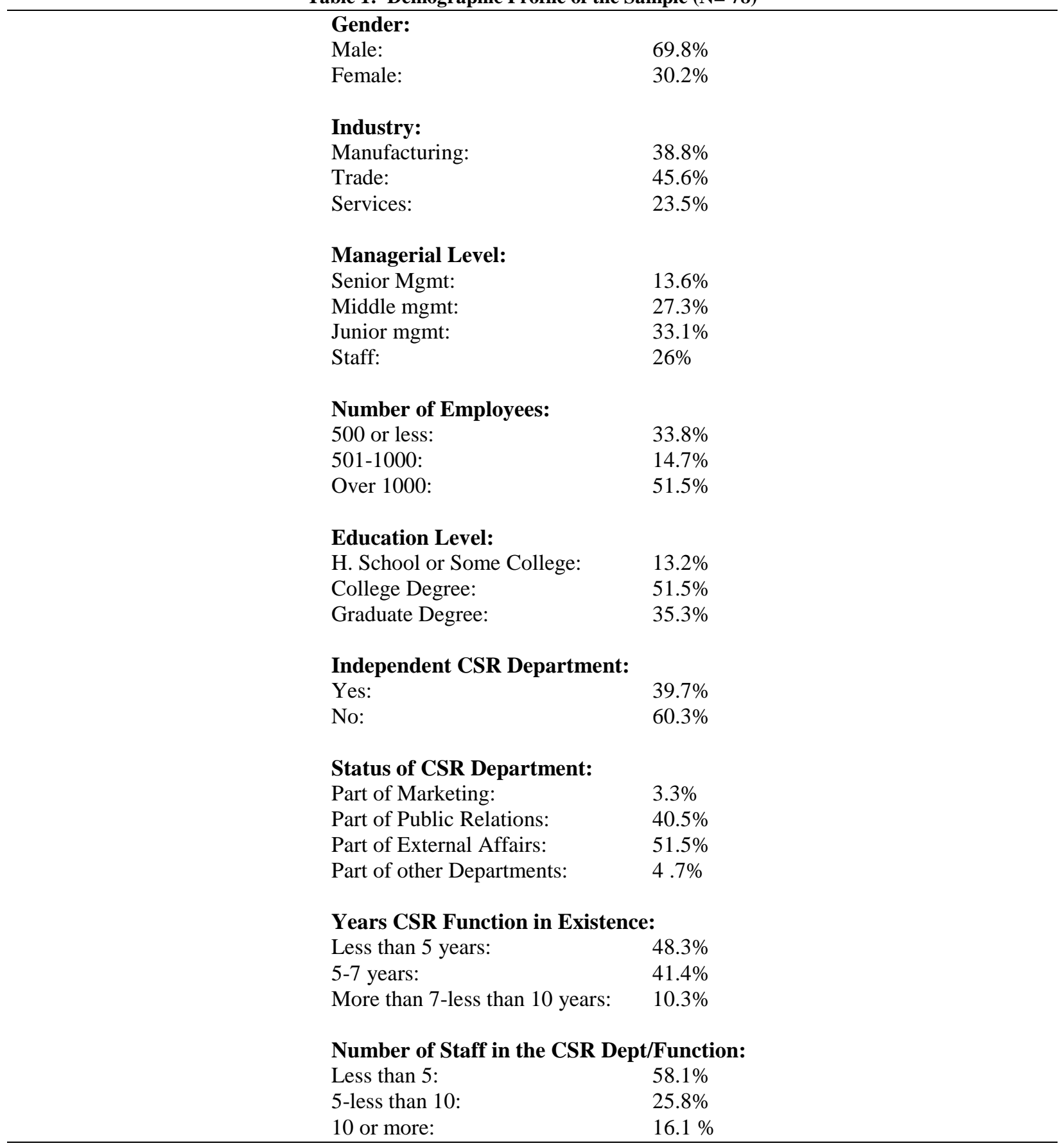




\section{RESULTS AND DISCUSSION}

\section{Awareness of and Attitude toward CSR}

Table 2 shows that Saudi Arabian managers are well aware of the concept of CSR and have a positive attitude toward it. However, they tend to be less enthusiastic when it comes to their perceptions of top management beliefs. This gap between managers' own perceptions and that of top management may be explained by the results shown in Table 3. Saudi managers perceive a lack of clear organizational policies that define and communicate resources needed to achieve social goals as well as a lack of organization-wide effort to become socially responsible. This also may be the cause for mangers' less enthusiastic perceptions of their top management commitment to CSR.

Table 2: Awareness and Attitude towards CSR

\begin{tabular}{|c|c|c|}
\hline Factor & Mean Score & Standard Deviation \\
\hline I am aware of the concept of Corporate Social Responsibility (CSR). & 4.15 & .72 \\
\hline Our firm is actively engaged in CSR. & 3.39 & 1.39 \\
\hline CSR is important to us. & 4.37 & .79 \\
\hline We believe that CSR helps our firm's reputation. & 4.31 & .90 \\
\hline $\begin{array}{l}\text { We do think it is our responsibility to give back to } \\
\text { the community we live in. }\end{array}$ & 3.88 & 1.07 \\
\hline We have invested money in CSR initiatives. & 3.57 & 1.01 \\
\hline Our top management belief in investing for future generation & 3.61 & 1.22 \\
\hline Our top management belief in sustainable growth for future generation & 3.60 & 1.16 \\
\hline
\end{tabular}

\section{Extent of CSR Integration in Corporate Policies}

Table 3 shows that Saudi managers are moderately confident that social goals are well integrated into their strategic goals and that both goals are operating harmoniously to achieve corporate goals. These results may be explained by several factors. Regarding the recency of the concept of CSR function in these organizations, almost $50 \%$ of the sampled firms have a CSR function that is five or less years old, they tend to be small departments of five or less employees, and the majority do not appear on the organizational chart as independent departments. Instead, the CSR function is integrated into the public relations or external affairs department of the organization (see table 1 for details). Such an organizational profile of the CSR function among Saudi Arabian firms indicates that the CSR concept is in the very early stage of its development in the country. Finally, the lack of full understanding of the CSR concept and its strategic role in the organization may have led top management to consider the CSR function as a propaganda function that is used to enhance the organization's unplanned well-being in its community rather than a strategic tool capable of enabling an organization to achieve its strategic goals.

Table 3: Extent of Social Goals Integration

\begin{tabular}{|c|c|c|}
\hline Activity & Mean Score & Standard Deviation \\
\hline We do have clear policies regarding spending our resources for meeting social goals. & 2.65 & 1.28 \\
\hline $\begin{array}{l}\text { There is an organization-wide effort in my company toward being a responsible } \\
\text { citizen within our community }\end{array}$ & 2.97 & 1.32 \\
\hline Social goals are a part of our firm's strategic goals. & 3.53 & 1.18 \\
\hline $\begin{array}{l}\text { Social goals are important to our firm since they do not conflict with our strategic } \\
\text { goals. }\end{array}$ & 3.10 & 1.11 \\
\hline
\end{tabular}




\section{CSR Activities}

\section{Natural Environment-oriented Activities}

Table 4 shows that while Saudi Arabian mangers have good intentions and positive attitudes toward preserving the natural environment, their employers lack any tangible policies regarding environmental preservation beyond those required by the law. As it is the case in many developing countries, country environmental laws tend to be minimal and flexible, both making compliance a poor indicator of any serious environmental commitment. The contradiction between attitude and behavior may be explained by the strong religious calling for preserving one's environment. In a sense, individual respondents may have acted based on their personal beliefs formed by their strong religious convictions for maximizing the common good. In summary, as previous research concluded, CSR among these firms tends to be anchored in a mix of personal and religious motivations, reflecting in a spontaneous altruistic philanthropic CSR orientation, and CSR activities tend to be less formalized, more sunken, and primarily oriented toward the local community in which a firm operates (Jamali et al., 2009; Amaeshi et al., 2006; Visser, 2008).

Table 4: Natural Environment-oriented Attitudes and Activities

\begin{tabular}{|l|c|c|}
\hline Activities/Believe & Mean Score & Standard Deviation \\
\hline We are concerned about our environment. & 3.14 & 1.19 \\
\hline $\begin{array}{l}\text { We as a business feel it is our responsibility to not harm the natural environment in } \\
\text { which we operate. }\end{array}$ & 4.33 & .77 \\
\hline We comply with our country's environmental law. & 4.18 & .96 \\
\hline We have explicit processes to meet environmental regulations with the Kingdom. & 2.85 & 1.29 \\
\hline We periodically assess the impact of our business on environment. & 2.54 & 1.21 \\
\hline We insist that our suppliers stick to stringent environmental guidelines. & 3.11 & 1.12 \\
\hline
\end{tabular}

\section{Community-oriented Activities}

Table 5 shows most CSR activities are less formalized, more sunken, and primarily oriented toward the local community in which a firm operates. Most of the community-oriented activities tend to focus on less formal, project-by-project activity, and are ad hoc in nature (Jamali et al., 2009; Amaeshi et al., 2006; Visser, 2008).

Table 5: Community-oriented Attitudes and Activities

\begin{tabular}{|c|c|c|}
\hline Activity & Mean Score & Standard Deviation \\
\hline As a firm we are engaged in community activities. & 3.72 & 1.05 \\
\hline We help local community through charitable donations. & 3.51 & 1.18 \\
\hline We feel a sense of responsibility toward our local community. & 3.99 & .93 \\
\hline We do not have specific guidelines in place to donate money to local charities. & 3.24 & 1.23 \\
\hline We are committed to the overall development of local community we operate in. & 3.91 & .94 \\
\hline We have sponsored many projects within local communities. & 3.81 & 1.12 \\
\hline Our company supports non-governmental organizations operating in our community & 3.13 & 1.01 \\
\hline Our company supports well being campaigns in our community & 3.47 & 1.19 \\
\hline
\end{tabular}

\section{Customer-oriented Activities}

Table 6 shows that Saudi Arabian firms tend to focus their customer-related CSR activities on a narrow set of activities related to customer satisfaction. This is a narrow definition of socially responsible customer orientation compared to those found in developed countries. More specifically, firms in developed countries focus their customer-related CSR activities on incorporating social characteristics or features into new products and manufacturing processes (e.g. developing environmental-friendly technologies), fair pricing practices, and fair competition. The difference in the scope of the developed and developing countries' definitions may be due to the 
import orientation of developing economies, such as that of the Saudi Arabian economy, as well as the absence of a sophisticated consumer goods manufacturing base that leaves Saudi Arabian firms too busy keeping sufficient throughput of imports in the market to meet growing customer demands.

Table 6: Consumer-oriented Activities

\begin{tabular}{|l|c|c|}
\hline Activity & Mean Score & Standard Deviation \\
\hline We care about consumer welfare. & 3.35 & .96 \\
\hline Our company respects consumer rights & 3.96 & .94 \\
\hline Our company provides accurate information to our customers & 3.73 & 1.04 \\
\hline Customers' satisfaction is important to our company & 3.83 & 1.09 \\
\hline
\end{tabular}

\section{Employee-oriented Activities}

Table 7 shows that Saudi firms are actually progressing in their responsibility toward their employees. Like western firms, Saudi firms are adopting progressive human resource management practices (e.g. promoting employee empowerment, providing acceptable work environments to employees).

Table 7: Employee-oriented Activities

\begin{tabular}{|l|c|c|}
\hline Activity & Mean Score & Standard Deviation \\
\hline Our company encourages its employees to participate in voluntarily activities. & 3.49 & 1.14 \\
\hline Our company policies encourage the employees to develop their skills and careers. & 3.82 & 1.12 \\
\hline $\begin{array}{l}\text { The management of our company is primarily concerned with employees' needs and } \\
\text { wants. }\end{array}$ & 3.62 & 1.12 \\
\hline $\begin{array}{l}\text { Our company implements flexible policies to provide a good work \& life balance for } \\
\text { its employees. }\end{array}$ & 3.50 & 1.09 \\
\hline The managerial decisions related with the employees are usually fair. & 3.34 & .97 \\
\hline Our company supports employees who want to acquire additional education. & 3.68 & 1.20 \\
\hline
\end{tabular}

\section{CONCLUSION}

This exploratory study attempted to shed light on the current status of CSR among Saudi firms. Results from a sample of managers indicated that while those managers are aware of the CSR concept and exhibit a positive attitude toward it, there is a disconnect between employee and top management attitude and perception of the concept. CSR is in its infancy among Saudi firms. The CSR concept is in the early stage of development and is reflective of the country's early stage of private sector development. There seems to be a narrow and shallow understanding of the strategic role of CSR in achieving overall long-term corporate objectives and limited CSR activities that seem to be localized and based on religious, individual or propaganda-oriented initiatives. CSR in Saudi Arabia tends to lean toward being classical and viewed as philanthropic/altruistic rather than strategic orientation. This is consistent with previous research in the region (Jamali et.al., 2008) who reported a high level of philanthropic orientation in Lebanon, Syria, and Jordan with small clusters of modern/strategic orientation in each country. The authors explain that this may be an indicator of a small group of Western educated Arab managers who belief in the added value of strategy, thus they are still trying to find the fit between their philanthropic tendencies and their business strategic goals. Arab managers have the ability and are ready to converge on a modernly defined CSR concept; however, for this to happen, top management-driven CSR initiatives have to be instituted, introduced, and communicated throughout the organization.

\section{AUTHOR INFORMATION}

Saud Mandurah is an Associate Professor of Business at the School of Economics and Administration, King Abdulaziz University. His research interest is focused in managerial issues in developing countries. E-mail: smandurah@kau.edu.sa 
Jamal Khatib is a Professor of Marketing at the University of St.Thomas. His research focus on ethics, corporate social responsibility and cross-cultural consumer behavior. E-mail: jaalkhatib@stthomas.edu (Corresponding author)

Saleh Al-Sabaan is an Associate Professor of Business at the School of Economics and Administration, King Abdulaziz University. His research interest is focused in managerial issues in developing countries. E-mail: binsabaan@yahoo.com

\section{REFERENCES}

1. Amaeshi, K., B. Adi, C. Ogbechi and O. Amao (2006). "CSR in Nigeria: Western Mimicry or Indigenous Influences?" The Journal of Corporate Citizenship 24, 83-99.

2. Collier, J., \& Esteban, R. (2007, January). Corporate social responsibility and employee commitment. Business Ethics: A European Review, 16(1), 19-33.

3. Deshpande, R. (1983). Paradigms lost: on theory and method in research in marketing. Journal of Marketing, 47 (3), 101-110

4. Dubey, P. (2008, September). Recycling Businesses: Cases of Strategic Choice for Green Marketing in Japan. IIMB Management Review, 20(3), 263-278.

5. European Commission: 2002, The Corporate Social Responsibility: A Business Contribution to Sustainable Development (Office of the Official Publications of the European Communities, Luxembourg) (online), http://ew.eea.europa.eu/industry/Reporting/cec corporate responsibility/com2001_036en01.pdf. Accessed April 4, 2012.

6. Ethical Investment Research Service, 2006

7. Ferns, B., Emelianova, O., \& Sethi, S. (2008, Summer2008). In His Own Words Sethi CSR Monitor. Corporate Reputation Review, 11(2), 116-129.

8. Ford, N. (2007, September). Corporate social responsibility in the African context. New African.

9. Glaser, B.G. \& Strauss, A.L. (1967). The discovery of grounded theory. Chicago, IL: Aldine.

10. Goyal, A. (2007), Corporate Social Responsibility as a Signaling Device for Foreign Direct Investment. International Journal of the Economics of Business, 13(1), 145-163.

11. Ingham, B. (2006, August). CSR: The wolf in sheep's clothing. Journal of Public Affairs (14723891), pp. 283,285 .

12. Jamali, D., M Zanhour and T. Keshishian (2009), "Peculiar Strengths and Relational Attributes of SMEs in the Context of CSR" Journal of Business Ethic 87 (3), 355-367.

13. Katsioloudes, M., \& Brodtkorb, T. (2007, September). Corporate Social Responsibility: An Exploratory Study in the United Arab Emirates. SAM Advanced Management Journal, 72(4), 9-20.

14. Khan M. (2008), ZGiving Back: Corporate Social responsibility in the GCC, accessed from http://www.zawya.com/story.cfm/sidZAWYA20070509115334?cc\&pass=1

15. Levine, M. (2008, November). China's CSR Expectations Mature. China Business Review, 35(6), 50-53.

16. Mackenzie, C. (2007, September). Boards, Incentives and Corporate Social Responsibility: the case for a change of emphasis. Corporate Governance: An International Review, 15(5), 935-943.

17. McWilliams, A., Siegel, D., \& Wright, P. (2006, January). Corporate Social Responsibility: Strategic Implications. Journal of Management Studies, 43(1), 1-18.

18. Snider, J., R. P. Hill and D. Martin (2003), Corporate Social Responsibility in the $21^{\text {st }}$ Century: A View from the World Most Successful Firms", Journal of Business Ethics 48, 175-187.

19. Visser. W. (2008), Corporate Social Responsibility in Developing Countries", in A. Crane, A. McWilliams, D. Matten, J. Moon and D.Siegel (eds), The Oxford Handbook of Corporate Social Responsibility, Oxford University Press, Oxford, pp. 473-503.

20. Votaw, D. (1973). Genius becomes rare, in D. Votaw and S. P. Sethi (eds.). The corporate dilemma: Traditional values and contemporary problems. Prentice Hall, New Jersey.

21. Whitehouse, L. (2003). Corporate social responsibility as citizenship and compliance: Initiatives on the domestic, European and global level. Journal of Corporate Citizenship, a, 85-98. 
NOTES 